\title{
Evaluasi Tingkat Kematangan e-Government Pada Partisipasi Masyarakat dan Pelayanan Publik Menerapkan Framework Gartner
}

\author{
Muhammad Miftahul Akbar ${ }^{1, *}$, Wing Wahyu Winarno², Kholid Haryono ${ }^{1}$ \\ ${ }^{1}$ Teknologi Industri, Teknik Informatika, Universitas Islam Indonesia, Yogyakarta, Indonesia \\ ${ }^{2}$ Sekolah Tinggi Ilmu Ekonomi YKPN, Yogyakarta, Indonesia \\ Email: 1,*16917214@ @students.uii.ac.id, ${ }^{2}$ wing@ykpn.ac.id, ${ }^{3}$ kholid.haryono@uii.ac.id \\ Email Penulis Korespondensi: 16917214@students.uii.ac.id
}

\begin{abstract}
Abstrak-E-Goverment sebagai bagian dari produk internet menjadi topik pembicaraan dalam diskusi internet maupun media masa dan popular setelah dihubungkan dengan kebijakan otonomi daerah kabupaten/kota di Indonesia. Namun masih banyak sistem informasi pemerintahan yang dibuat dan diimplementasikan tidak berfungsi secara maksimal baik tingkat pemerintahan daerah maupun pusat. Mengukur tingkat kematangan E-government dibutuhkan untuk mengetahui sejauh mana keberhasilan penerapan E-government. Tujuan dari penilaian kematangan E-government untuk menyediakan data dasar, data lanjutan, dan semua yang diperlukan untuk pengembangan strategi E-government. Gartner adalah salah satu model yang digunakan untuk mengukur tingkat kematangan e-government. Model Gartner menyarankan empat fase kritis dari evolusi $e$ government yaitu : kehadiran web, interaksi, transaksi, dan transformasi. Model gartner digunakan untuk mengukur maturity level di kabupaten Sukoharjo. Methodology penelitian menggunakan kuisioner dan perhitungan menggunakan rata-rata skor setiap dimensi. Untuk mengetahui hubungan antara dimensi dengan kriteria digunakan metode PLS (Partial Least Square). Penelitian membuktikan tingkat kematangan E-government sebesar 4,06 (predictable process). Dimensi transformasi dan usability berpengaruh terhadap partisipasi masyarakat menggunakan e-government di kabupaten Sukoharjo.
\end{abstract}

Kata Kunci: E-government; Tingkat Kematangan (Maturity Level); Model Gartner; Tingkat Partisipasi Masyarakat; Tata Kelola; Sistem Informasi; PLS; Stage Maturity Model (SMM)

Abstract-E-government as part of internet products has become a topic of discussion in internet and mass media discussions and is popular after being linked to the regional autonomy policy of districts / cities in Indonesia. However, there are still many government information systems that are developed and implemented that do not function optimally at both the regional and central government levels. Measuring the level of E-government maturity is needed to determine the extent to which the successful application of E-government is. The purpose of the E-government maturity assessment is to provide basic data, advanced data, and all that is necessary for the development of an E-government strategy. Gartner is one of the models used to measure the maturity level of e-government. Gartner's model suggests four critical phases of the evolution of e-government, namely: web presence, interaction, transactions, and transformation. The gartner model is used to measure the maturity level in Sukoharjo district. The research methodology used a questionnaire and the calculation used the average score for each dimension. To determine the relationship between dimensions and criteria, the PLS (Partial Least Square) method is used. Research has proven that the maturity level of E-government is 4.06 (predictable process). The dimensions of transformation and usability affect community participation using e-government in Sukoharjo district.

Keywords: E-government; Maturity Level; Gartner Model; Community Participation Level; Governance; Information Systems; PLS; Stage Maturity Model (SMM)

\section{PENDAHULUAN}

Tata kelola pemerintahan di Indonesia pada era teknologi 4.0 diharuskan mengikuti perubahan dan menampung setiap aspirasi masyarakat secara cepat. Sejak tahun 2003 melalui Inpres No. 3, pemerintah Indonesia memiliki inisiatif untuk membuat keterbukaan informasi melalui pengembangan E-government. Dalam inpres setiap penyelenggara pemerintahan dituntut menyelenggarakan pemerintahan yang bersih, transparan dan mampu menjawab tuntutan perubahan secara efektif [1]. Pada tahun 2018 pemerintah mengeluarkan peraturan presiden republik Indonesia nomor 95 tahun 2018 tentang sistem pemerintahan berbasis elektronik. Dalam perpres tersebut pemerintah berharap peningkatan kualitas penyelenggaraan administrasi pemerintahan dan peningkatan partisipasi masyarakat dalam pembangunan lewat sistem pemerintahan berbasis elektronik (e-government). Dalam perpres 2018, pemerintah memasukkan SPBE menjadi Rencana Pembangunan Jangka Panjang (RPJP) Nasional 2005-2025.

E-government berkaitan dengan penggunaan teknologi informasi (Seperti Wide Area Network, internet, dan komunikasi bergerak) oleh lembaga pemerintahan yang mempungai kemampuan untuk mentransformasikan hubungan pemerintah dengan warganya (G2C), pelaku dunia usaha (bisnis) (G2B), dan lembaga pemerintahan lainnya (G2B) [2]. Tingkat partisipatif dan keterbukaan menjadi kelebihan dari E-government dalam memutus sekat pemisah antara pemerintah dengan masyarakat di Indonesia. Menurut survei yang dilakukan oleh EDGI ( $E$ government Development Index) pada tahun 2018 Indonesia menempati peringkat 107 naik dari peringkat 116 pada survei EDGI 2016. Dengan nilai EDGI 0,5258 menempatkan Indonesia masih di bawah Malaysia (Peringkat EDGI 48), Singapura (Peringkat EDGI 7), Brunei Darussalam (Peringkat EDGI 59), Thailand (Peringkat EDGI 73), Filipina (Peringkat EDGI 75), dan Vietnam (Peringkat EDGI 88) [3]. 
Tingkat partisipasi masyarakat yang terus meningkat menginginkan birokrasi terbuka menjadikan $E$ government sangat dibutuhkan di Indonesia. Namun masih banyak sistem informasi pemerintahan yang dibuat dan diimplementasikan tidak berfungsi secara maksimal baik tingkat pemerintahan daerah maupun pusat. Hal tersebut diungkapkan pada sebuah penelitian [4] yang membuktikan pada 110 proyek sistem informasi yang berjalan di pemerintahan hanya $27 \%$ proyek sistem infomasi terselesaikan sesuai anggaran dan tepat waktu, sementara sisanya $55 \%$ bermasalah dan $10 \%$ proyek dibatalkan.

Menurut [5] tantangan terbesar dalam implementasi E-government di Indonesia adalah kemampuan dan kesiapan manajemen dalam menerima perubahan dan budaya bekerja menggunakan E-government. Ada beberapa hambatan berikutnya yang menjadi konsen penerapan E-government diantaranya beberapa daerah di Indonesia masih belum tersentuh jaringan komunikasi secara komersil, sharing informasi antar lembaga masih sangat rendah, dan sumber daya manusia yang belum mempunyai kultur mendokumentasikan setiap pekerjaan secara digital. Sebagai contoh pada survei E-government yang dilakukan Dirjen Komunikasi dan Informasi Jawa Tengah pada tahun 2017 dari 35 Kabupaten/ Kota hanya 10 kota yang memenuhi kriteria E-government dengan penilaian baik. Kegagalan dari penerapan E-government karena tingkat kematangan (maturity level) sistem masih rendah atau belum sesui dengan harapan.

Mengukur tingkat kematangan E-government dibutuhkan untuk mengetahui sejauh mana keberhasilan penerapan E-government pada organisasi pemerintah sesuai dengan standard regulasi yang berlaku [6]. Tujuan dari penilaian kematangan E-government untuk menyediakan data dasar, data lanjutan, dan semua yang diperlukan untuk pengembangan strategi E-government. Penilaian tingkat kematangan (maturity) membantu mengidentifikasi prioritas dari pengembangan E-government untuk meningkatkan daya saing dan pemenuhan informasi bagi masyarakat [7].

Pengukuran tingkat kematangan menjadi acuan yang bisa digunakan untuk memperbaiki sistem yang telah digunakan pada pemerintah. Untuk itu perlu model yang tepat agar mendapatkan analisa tingkat kematangan e-government yang sesuai dan dapat dievaluasi. Sehingga tingkat partisipasi dan pengguna sistem informasi pemerintah menjadi meningkat dan menyediakan informasi sesuai dengan kebutuhan masyarakat. Dengan adanya pengukuran tingkat kematangan E-government dapat menunjukkan perubahan pola dan struktur dalam pengembangan E-government menjadi lebih baik.

Ada 2 hal yang akan dibahas pada penelitian ini. Pertama bagaimana mengukur tingkat kematangan $e$ government di kabupaten sukoharjo. Kedua, faktor apa yang berpengaruh terhadap tingkat partisipasi masyarakat menggunakan e-government di kabupaten Sukoharjo.

\section{METODOLOGI PENELITIAN}

\subsection{Tahapan Penelitian}

Penulis menyusun langkah-langkah penelitian yang sistematis agar penelitian ini lebih terarah. Tahapan penelitian tersebut penulis disajikan dalam bentuk diagram alur berikut ini kerangka model gartner sesuai kebutuhan pengukuran sistem.

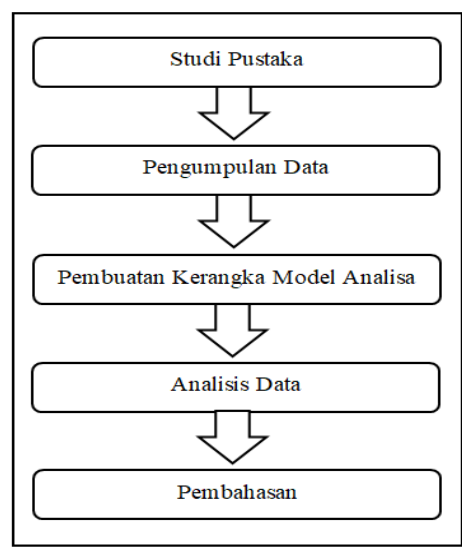

Gambar 1. Bagan Penelitian

\subsection{Studi Pustaka}

Penelitian pengukur tingkat kematangan E-government di pemerintah daerah Indonesia ini mengacu pada beberapa penelitian terkait sebelumnya. Pada penelitian [8] E-government Bangladesh untuk mengukur tingkat kesiapan E-government karena beberapa sistem yang sudah dibangun dan diimplementasikan oleh pemerintah tidak terpakai menggunakan model Gartner. Penelitian [8] menyebutkan kegagalan implementasi pada fase 
interaksi yang dilakukan pemerintah. Alasan utama karena tidak ada aturan atau undang-undang yang mengatur dalam mempromosikan dan melaksanakan e-government.

Kemudian pada penelitian yang dilakukan di Dubai juga menggunakan model Gartner. Perbedaan yang mendasar, penelitian tersebut mengukur tata kelola E-government. Walau pun sudah 97,5\% tingkat keberhasilan E-government namun masih memiliki masalah yang mendasar. [9] Menyebutkan Dubai masih kurang dalam faktor keberhasilan G2C (Government to Citizen). Data yang digunakan hanya berasal dari jurnal, website pemerintah dan surat kabar sehingga keakuratan data masih kurang.

Pada penelitian E-government pemerintah lokal di Amerika Selatan. Peneliti berpendapat E-government bukan hanya sebatas website pemerintahan saja, tetapi mencakup konsep-konsep seperti transparansi, akuntabilitas, dan partisipasi warga dalam evaluasi kinerja pemerintah [10]. Dengan menggunakan model Gartner penelitian tersebut menemukan beberapa daerah di Amerika Selatan masih sangat kurang dalam kesiapan E-government.

Beberapa penelitian tersebut diatas menjadi dasar pada penelitian yang dilakukan penulis. Masih ada penelitian yang ditulis oleh [11] [12] dan [13] yang membandingkan berbagai model dalam mengukur tingkat kematangan. Secara teori berdasar literatur yang diperoleh, penelitian ini akan menguji tingkat kesiapan pemerintah daerah menggunakan model Gartner dengan 4 fase untuk mendapatkan indeks kesiapan pemerintah dalam penggunaan dan pemanfaatan E-government.

\subsubsection{Gartner Model}

Gartner adalah salah satu model yang digunakan untuk mengukur tingkat kematangan e-government. Seperti pada Ada banyak framework atau model yang bisa digunakan untuk melakukan pengukuran khususnya pada tingkat kematangan (maturity level) e-government. D. Napitupulu, (2016) menyebutkan ada 25 model yang bisa digunakan dalam mengukur tingkat kematangan E-government.

Model Gartner pertama kali dikenalkan pada tahun 2000. Gartner mendemonstrasikan kemajuan $e$ government dalam empat tahap tingkat kematangan e-government. Fokus analisa tingkat kematangan model gartner menekankan pada integrasi sistem dan teknologi. Gartner banyak digunakan pada analisa tingkat kematangan e-government negara-negara maju. Model gartner lebih cocok untuk negara maju yang memiliki teknologi terkini, dan lebih banyak masalah non-teknis seperti konsentrasi pada kesadaran publik dan kesiapan elektronik. Meskipun begitu, ada beberapa model lokal menjadikan gartner sebagai model acuan dalam pembuatan kerangka kerja (frame work) analisa kematangan e-government. Model Gartner menyarankan empat fase kritis dari evolusi e-government yaitu : keberadaan web, interaksi, transaksi, dan transformasi [8].

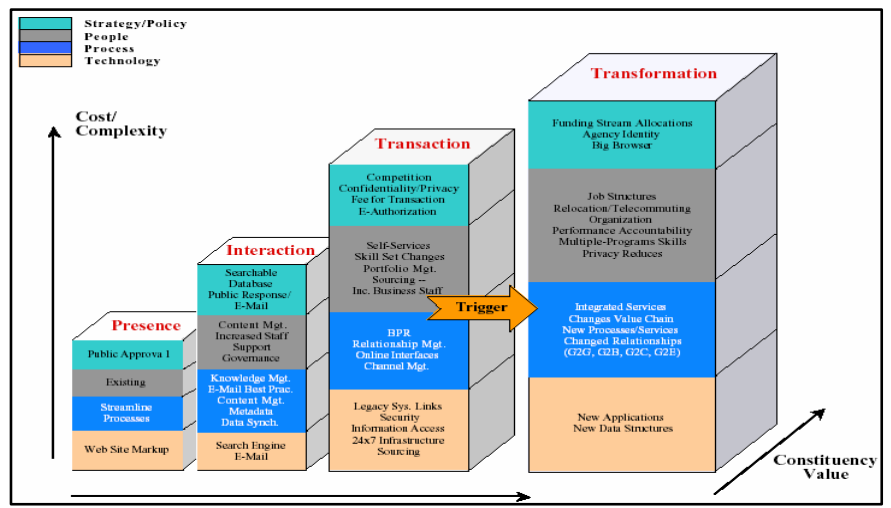

Gambar 2. Framework Gartner [14]

Dari Gambar 2 dapat dilihat dari 4 fase diatas memiliki keterkaitan dan saling berhubungan. Fokus model gartner melakukan analisa proses integrasi pada tingkat sistem. Pemilihan Gartner sebagai model penilaian kematangan sesuai digunakan pada pemerintahan daerah yang berada di Indonesia. Analisa dilakukan 2 arah dari sisi pemerintah dan warga masyarakat yang merasakan dan menggunakan e-government. Penjelasan dari empat fase adalah sebagai berikut:

a. Keberadaan Website

Website yang dapat memberikan informasi seperti visi misi pemerintah, alamat kantor pemerintah, jam buka pelayanan pemerintah, dan beberapa dokumen resmi yang relevan dengan publik.

b. Interaksi

Beberapa fasilitas seperti kemampuan pencarian dasar, formulir untuk pengaduan, tautan ke situs yang relevan dan alamat email para pejabat terkait.

c. Transaksi

Membangun aplikasi yang memungkin publik dapat melakukan pembayaran kewajiban secara online dan mandiri. Seperti pembayaran pajak dan pembaruan segala jenis ijin.

d. Transformasi 


\section{JURNAL MEDIA INFORMATIKA BUDIDARMA}

Volume 5, Nomor 1, Januari 2021, Page 99-107

ISSN 2614-5278 (media cetak), ISSN 2548-8368 (media online)

Available Online at https://ejurnal.stmik-budidarma.ac.id/index.php/mib

DOI 10.30865/mib.v5i1.2606

Penyampaian layanan pemerintah yang didefinisikan ulang dengan melawati satu titik. Seperti penyediaan

pelayanan "One Stop Shop" pada e-government.

\subsection{Pengumpulan Data}

Lokasi penelitian berada di kabupaten Sukoharjo. Kabupaten sukoharjo memiliki 18 Dinas, 4 Badan Pemerintah, dan 12 Kecamatan yang sudah menerapkan e-government (Sistem Informasi Pemerintah Elektronik) dalam melayani masyarakat. E-government Kabupaten Sukoharjo pertama kali dibuat pada tahun 2006 sebagai sistem informasi pemerintahan. Pada penelitian ini penulis menggunakan pendekatan metode kuantitif. Penulisan akan menggunakan 2 metode pengumpulan data yaitu wawancara dan menggunakan observasi dalam penelitian yang telah lalu atau sumber yang disediakan oleh obyek penelitian. Untuk mendapatkan data dalam bentuk angka dilakukan dengan menyebar kuisioner dengan skala penilaian 1 sampai 5.

Tabel 1. Skor Tingkat Kematangan [6]

\begin{tabular}{lll}
\hline Skor Kematangan & Level & Keterangan Skor \\
\hline $1,00-1,50$ & 1 & Incomplete Process \\
$1,51-2,50$ & 2 & Performed Process \\
$2,51-3,50$ & 3 & Estabilished Process \\
$3,51-4,50$ & 4 & Predictable Process \\
$4,51-5,00$ & 5 & Optimizing Process \\
\hline
\end{tabular}

Pendefinisian tingkat kematangan suatu proses teknologi informasi untuk mengukur tingkat kematangan TI dengan menggunakan metode penilaian (scoring). Selanjutnya, untuk merelasikan antara nilai tingkatan dan nilai absolut yang dilakukan dengan perhitungan dalam bentuk formula matematika. Persamaan matematik untuk menentukan nilai kematangan sistem adalah sebagai berikut:

Nilai Kematangan Setiap Dimensi per Responden $=\frac{\text { JJawaban Kuisioner }}{\text { SPertanyaan Kuisioner }}$

Nilai Kematangan Setiap Dimensi per Responden $=\frac{\sum \text { Jawaban Kuisioner }}{\text { PPertanyaan Kuisioner }}$

Tingkat Kematangan E - Government Menggunakan Gartner

$$
=\frac{\sum \text { Tingkat Kematangan Dimensi }}{\sum \text { Dimensi Yang Dipakai }}
$$

\subsection{Pembuatan Kerangka Model Analisa dan Penyusunan Hipotesis}

Penetapan indikator yang dijadikan sebagai kerangka model analisa dan penilaian mengacu pada penelitian yang dilakukan oleh [7]. Metode yang digunakan untuk melakukan penilain tingkat kematangan adalah Stage Maturity Model (SMM). Untuk lebih jelasnya dapat dilihat pada Tabel 2. Pada tabel tersebut berisi poin yang akan diterjemahkan untuk pembuatan kuisioner sesuai dengan kerangka Model Gartner.

Tabel 2. Indikator Penilaian (Stage Maturity Model)

\begin{tabular}{clc}
\hline Variabel & \multicolumn{1}{c}{ Indikator } & Kode \\
\hline Presence (X1) & Kesiapan Organisasi (OR) & X11 \\
& Tata Kelola dan Kesiapan Kepemimpinan (GLR) & X12 \\
& Kesiapan Pemangku Kepentingan (CR) & X13 \\
& Kesiapan Sumber Daya Manusia (HR) & X14 \\
& Kesiapan Teknologi (TR) & X15 \\
& Kesiapan Hukum dan Aturan yang Ada (LR) & X16 \\
Interaksi (X2) & Kesiapan Organisasi (OR) & X21 \\
& Tata Kelola dan Kesiapan Kepemimpinan (GLR) & X22 \\
& Kesiapan Pemangku Kepentingan (CR) & X23 \\
& Kesiapan Sumber Daya Manusia (HR) & X24 \\
& Kesiapan Teknologi (TR) & X25 \\
& Kesiapan Hukum dan Aturan yang Ada (LR) & X26 \\
Transaksi (X3) & Kesiapan Organisasi (OR) & X31 \\
& Tata Kelola dan Kesiapan Kepemimpinan (GLR) & X32 \\
& Kesiapan Pemangku Kepentingan (CR) & X34 \\
& Kesiapan Sumber Daya Manusia (HR) & X35 \\
& Kesiapan Teknologi (TR) & X36 \\
& Kesiapan Hukum dan Aturan yang Ada (LR) & X41 \\
Transformasi & Kesiapan Organisasi (OR) & X42 \\
& Tata Kelola dan Kesiapan Kepemimpinan (GLR) & X43 \\
\hline
\end{tabular}


JURNAL MEDIA INFORMATIKA BUDIDARMA

Volume 5, Nomor 1, Januari 2021, Page 99-107

ISSN 2614-5278 (media cetak), ISSN 2548-8368 (media online)

Available Online at https://ejurnal.stmik-budidarma.ac.id/index.php/mib

DOI 10.30865/mib.v5i1.2606

\begin{tabular}{clc}
\hline Variabel & \multicolumn{1}{c}{ Indikator } & Kode \\
\hline & Kesiapan Sumber Daya Manusia (HR) & X44 \\
& Kesiapan Teknologi (TR) & X45 \\
& Kesiapan Hukum dan Aturan yang Ada (LR) & X46 \\
Usability (X5) & X51 \\
& Kesiapan Organisasi (OR) & X52 \\
& Tata Kelola dan Kesiapan Kepemimpinan (GLR) & X53 \\
& Kesiapan Pemangku Kepentingan (CR) & X54 \\
& Kesiapan Sumber Daya Manusia (HR) & X55 \\
& Kesiapan Teknologi (TR) & X56 \\
& Kesiapan Hukum dan Aturan yang Ada (LR) & X57 \\
& Kemudahan Pengguna (KP) & X58 \\
& Keterbukaan data dan Informasi (KD) & X59 \\
& Pelayanan Publik (PP) & X510 \\
& Ketertarikan Masyarakat (KM) & Y1 \\
Kesiapan Organisasi (OR) & Y2 \\
Tata Kelola dan Kesiapan Kepemimpinan (GLR) & Y3 \\
& Kesiapan Pemangku Kepentingan (CR) & Y4 \\
& Kesiapan Sumber Daya Manusia (HR) & Y5 \\
Kesiapan Teknologi (TR) & Y6 \\
& Kesiapan Hukum dan Aturan yang Ada (LR) & Y7 \\
& Kemudahan Pengguna (KP) & Y8 \\
Keterbukaan data dan Informasi (KD) & Y9 \\
Pelayanan Publik (PP) & Y10 \\
Ketertarikan Masyarakat (KM) &
\end{tabular}

Model kerangka teoritis hubungan antar variabel ditunjukkan pada Gambar 3. Kerangka yang sudah dibangun selanjutnya ditransformasikan ke dalam bentuk diagram jalur untuk menggambarkan hubungan kausalitas antar variabel tersebut. Dalam penelitian ini terdapat satu variabel dependen (Partisipasi) dan lima variabel independen (Keberadaan Website, Interaksi, Transaksi, Transformasi, dan Usability).

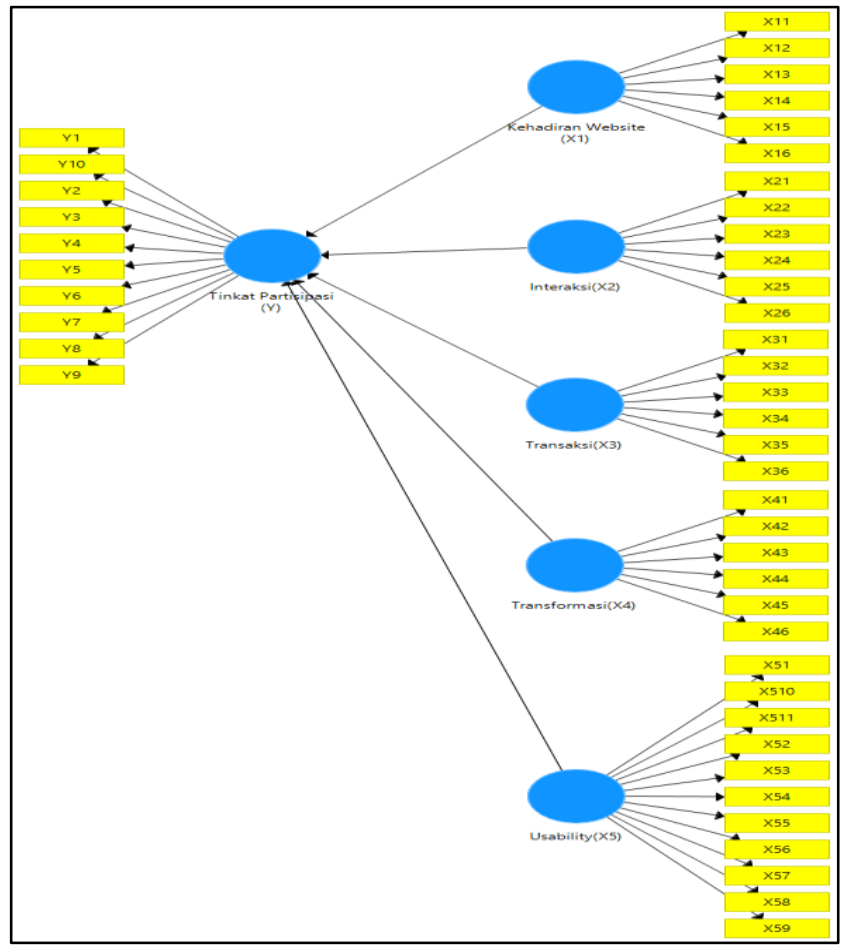

Gambar 3. Hipotesis Penilitian

\section{HASIL DAN PEMBAHASAN}

Pada bagian ini berisi hasil dan pembahasan dari topik penelitian, yang bisa di buat terlebih dahulu metodologi penelitian.

\subsection{Gambaran Umum Responden}


ISSN 2614-5278 (media cetak), ISSN 2548-8368 (media online)

Available Online at https://ejurnal.stmik-budidarma.ac.id/index.php/mib DOI 10.30865/mib.v5i1.2606

Penelitian ini dilakukan di Kabupaten Sukoharjo. Responden yang mengisi kuisioner sebanyak 92 responden. Responden terdiri dari pengelola sistem dan dari kepala dinas yang menggunakan e-government.

Tabel 3. Responden Menurut Umur

\begin{tabular}{cc}
\hline \multicolumn{2}{c}{ Responden Menurut Umur } \\
Rentan Umur & Jumlah \\
\hline 20-35 Tahun & 38 \\
36-45 Tahun & 21 \\
46-55 Tahun & 23 \\
Diatas 56 Tahun & 10 \\
\hline
\end{tabular}

Pada Tabel 3 menunjukkan rentan umur pegawai atau yang dijadikan obyek penelitian paling banyak rentan umur 20-35. Responden menurut instansi kerja dapat dilihat pada Tabel 4. Disini penulis hanya menyebutkan OPD (Organisasi Perangkat Daerah) dengan Dinas, Badan, Kecamatan, dan Desa karena jumlah OPD sendiri sudah banyak sekitar 45 OPD sehingga penulis mengelompokkan menurut cluster.

Tabel 4. Cluster Responden Menurut OPD (Organisasi Pemerintah Daerah)

\begin{tabular}{cc}
\hline \multicolumn{2}{c}{ Responden Menurut SKPD } \\
Tempat Bekerja & Jumlah \\
\hline Dinas Pemda & 43 \\
Badan Pemda & 18 \\
Kecamatan & 23 \\
Kelurahan & 8 \\
\hline
\end{tabular}

\subsection{Analisis dan Penghitungan Data}

Hasil analisa dan observasi data didapatkan nilai dari masing-masing dimensi yang terdapat pada model gartner yang digunakan. Penghitungan data menggunakan excel didapatkan 6 nilai pada masing-masing dimensi pengukuran. Model gartner menunjukkan dimensi kematangan setiap kriteria berdasar dimensi keberadaan , interaksi, transaksi serta transformasi. Sementara 2 dimensi tambahan memiliki kriteria yang sama hanya ditambahkan dengan 4 kriteria penilai yaitu Kemudahan Pengguna (KP), Keterbukaan data dan Informasi (KD), Pelayanan Publik (PP) serta Ketertarikan Masyarakat (KM). Hasil dari penilaian kematangan sistem secara keseleruhan dapat dilihat pada Tabel 5. Hasil pengukuran setiap dimensi dari setiap kriteria didapatkan dari jumlah nilai kuisioner dari 92 responden setiap dimensi pada setiap kriteria.

Tabel 5. Hasil Pengukuran Menggunakan Model Gartner

\begin{tabular}{|c|c|c|c|c|c|c|}
\hline Dimensi & Keberadaan & Interaksi & Transaksi & Transformasi & Partisipasi & Usability \\
\hline Kesiapan Organisasi (OR) & 365 & 379 & 371 & 382 & 373 & 369 \\
\hline Tata Kelola dan Kesiapan & 366 & 371 & 374 & 376 & 376 & 372 \\
\hline Kepemimpinan (GLR) & & & & & & \\
\hline $\begin{array}{l}\text { Kesiapan pemangku kepentingan } \\
\text { (CR) }\end{array}$ & 361 & 380 & 358 & 381 & 372 & 369 \\
\hline $\begin{array}{l}\text { Kesiapan sumber daya manusia } \\
\text { (HR) }\end{array}$ & 384 & 366 & 354 & 361 & 375 & 378 \\
\hline Kesiapan teknologi (TR) & 386 & 381 & 360 & 377 & 368 & 333 \\
\hline $\begin{array}{l}\text { Kesiapan hukum dan aturan yang } \\
\text { ada (LR) }\end{array}$ & 382 & 399 & 378 & 381 & 385 & 376 \\
\hline Kemudahan Pengguna (KP) & - & - & - & - & 369 & 357 \\
\hline $\begin{array}{l}\text { Keterbukaan data dan Informasi } \\
\text { (KD) }\end{array}$ & - & - & - & - & 339 & 378 \\
\hline Pelayanan Publik (PP) & - & - & - & - & 378 & 381 \\
\hline Ketertarikan Masyarakat (KM) & - & - & - & - & 389 & 385 \\
\hline Jumlah Skor & 2244 & 2276 & 2195 & 2258 & 3698 & 3724 \\
\hline Rata-Rata & 4.08 & 4.12 & 3.98 & 4.10 & 4.05 & 4.01 \\
\hline
\end{tabular}

Dari tabel Tabel 5 rata-rata nilai tertinggi tingkat kematangan e-government di Kabupaten sukoharjo tertinggi pada dimensi Interaksi berada pada nilai 4.12 (Predictable Process), ini menunjukkan adanya interaksi sistem yang kuat antara pengguna dengan e-government. Sementara pada Dimensi Transformasi 4.01 (Predictable Process). Hal ini menunjukkan bahwa e-government sukoharjo sudah mampu mengikuti dan melakukan perubahan. Nilai terendah pada dimensi transaksi sebesar 3.98 (Esthabilished Process). Walaupun masuk dalam esthabilished process, hal ini membuktikan bahwa e-government di Kabupaten Sukoharjo masih kurang dari segi kematangan e-government dimensi transaksi. Dalam sesi wawancara pun narasumber juga menyatakan bahwa masih ada perbaikan dalam sistem dari segi pelayanan kepada publik lewat e-government baik dari segi transaksi.

Dimensi keberadaan (presence) berada pada nilai 4.08 (Predictable Process). Angkat tersebut menunjukkan bahwa hampir seluruh OPD di kabupaten Sukoharjo telah memiliki sistem/ website bagi setiap 
OPD. Sementara dimensi tambahan Usability berada pada angka 4.01 (Predictable Process), hal tersebut membuktikan bahwa pegawai/pengelola sudah mempunyai keahlian atau terdapat pendampingan secara terstruktur dalam pengelolaan e-government. Tingkat partisipasi masyarakat atau pengelola dalam menggunakan e-government berada pada angka 4.05 (Predictable Process). Hal tersebut menunjukan bahwa pengelola sudah terbiasa dengan adanya e-government dalam mempermudah pekerjaan dan masyarakat sukoharjo sudah mengenal e-government kabupaten sukoharjo. Sehingga proses pengembangan lebih lanjut dapat lebih mudah karena masyarakat sudah lebih percaya dengan kelebihan e-government dari segi transparansi atau keterbukaan informasi pemerintah. Secara keseluruhan level tingkat kematangan E-government di kabupaten Sukoharjo berada pada skor 4.06 (Predictable Process). Artinya tingkat kematangan e-government menurut model dalam ambang batas sudah dapat diprediksi baik secara pengelolaan dan pengawasan.

\subsection{Faktor Yang Berpengaruh terhadap Tingkat Partisipasi}

Tingkat partisipasi masyarakat menggunakan e-government dipengaruhi berbagai faktor yang ada. Pada penelitian ini model gartner digunakan sebagai faktor yang mempengaruhi tingkat partisipasi masyarakat. Selain itu dimensi usability juga dijadikan faktor yang mempengaruhi tingkat partisipasi masyarakat menggunakan $e$ government.

Untuk mendapatkan analisis faktor yang mempengaruhi tingkat partisipasi masyarakat digunakan metode PLS SEM. Data penelitian yang telah dikumpulkan dilakukan analisis untuk membuktikan hipotesis. Data dinalisis dengan metode PLS SEM dengan menggunakan Software SmartPLS. Metode PLS dilakukan dua tahap yaitu model pengukuran (evaluasi outer model) dan model struktural (evaluasi inner model). Dalam hal ini, dimensi partisipasi (Y) digunakan sebagai variable dependent, sedangkan dimensi keberadaan website (X1), dimensi interaksi (X2), dimensi transaksi (X3), dimensi transformasi (X4), dan dimensi usability (X5) sebagai variable independent.

Dari bagan penelitian pada Gambar 3 akan dibangun beberapa hipotesis sesuai dengan model yang telah dibangun. Hipotesis kemudian akan diujikan dan dianalisa dengan metode PLS SEM

H1 : Dimensi keberadaan website (X1) akan berpengaruh positif terhadap tingkat partisipasi masyarakat (Y)

Dimensi keberadaan website adalah tersedianya website yang dapat memberikan informasi seperti visi misi pemerintah, alamat kantor pemerintah, jam buka pelayanan dan beberapa dokumen resmi yang relevan dengan publik [14]. Tampilan website dengan desain yang unik, estetis, dan kreatif baik dari segi tata letak menjadi daya tarik bagi pengunjung website [15]. Hal ini dapat mempengaruhi tingkat partisipasi masyarakat menggunakan e-government.

H2 : Dimensi interaksi (X2) akan berpengaruh positif terhadap tingkat partisipasi masyarakat (Y) Dimensi Interaksi adalah tersedianya beberapa fasilitas website untuk melakukan pencarian, formulir pengaduan, tautan ke situs yang relevan dan adanya alamat e-mail para pejabat terkait [16]. Interaksi menujukkan hubungan antara government to citizen (G2C) yang baik. Adanya interaksi yang baik dapat menunjukkan tingkat partipasi masyarakat dalam menggunakan e-government.

H3 : Dimensi transaksi(X3) akan berpengaruh positif terhadap tingkat partisipasi masyarakat (Y) Dimensi transaksi adalah adanya layanan on-line yang memungkinkan masyarakat untuk melakukan pembayaran kewajiban secara online dan mandiri serta pengurusan segala jenis ijin [16]. Kemudahan melakukan transaksi menggunakan e-government kemungkinan dapat meningkatkan tingkat partisipasi masyarakat.

H4 : Dimensi transformasi (X4) akan berpengaruh positif terhadap tingkat partisipasi masyarakat (Y)

Dimensi Transformasi adalah adanya pengembangan sistem pada tingkat yang lebih baik. Seperti penyediaan layanan One Stop Shop (OSS) pada e-government. transformasi e-government dapat digunakan untuk pembangunan masyarakat informasi, meningkatkan iklim investasi \& kompetisi, meningkatkan transparansi, akuntabilitas, dan good governance, meningkatkan partisipasi masyarakat [15]. Hal ini kemungkinan dapat mempengaruhi tingkat partisipasi masyarakat dengan adanya transformasi.

H5 : Dimensi usability (X5) akan berpengaruh positif terhadap tingkat partisipasi masyarakat (Y)

Dimensi Usability (Kemudahan) adalah kemudahan dalam penggunaan website seperti kemudahan pembacaan dan pemahaman informasi di web, kemudahan mencari informasi. Kemudahan dalam pengoperasian e-government dapat meningkatkan partipasi masyarakat [15]. Dimensi Usability kemungkinan berpengaruh terhadap tingkat partisipasi masyarakat.

Sedangkan data yang digunakan adalah rata-rata dimensi setiap responden. Rata-rata dimensi didapatkan dari setiap kriteria yang dijumlahkan dan dibagi dengan jumlah dimensi sehingga didapatkan rata-rata dari setiap dimensi per responden.

$$
\text { Rata }- \text { Rata Dimensi Setiap Responden }=\frac{\text { LJawaban Kuisioner }}{\text { SPertanyaan Kuisioner }}
$$

\subsubsection{Evaluasi Outer Model}


JURNAL MEDIA INFORMATIKA BUDIDARMA

Volume 5, Nomor 1, Januari 2021, Page 99-107

ISSN 2614-5278 (media cetak), ISSN 2548-8368 (media online)

Available Online at https://ejurnal.stmik-budidarma.ac.id/index.php/mib

DOI 10.30865/mib.v5i1.2606

Pada tahap evaluasi outer model dilakukan pengujian validitas dan reabilitas. Uji validitas digunakan untuk mengukur indicator yang menyusun variabel, sedangkan uji reliabilitas digunakan untuk menguji variabel yang menyusun model.

Uji validitas dilakukan dengan mengukur nilai faktor loading (FL) dan cross loading setiap indicator. Ambang batas nilai faktor loading adalah $\geq 0.5$, sedangkan nilai cross loading harus lebih besar dari nilai cross loading loading pada variabel [17]. Pada pengukuran awal nilai FL pada indicator X31, X34, X51, dan X53 memiliki nilai FL kurang dari 0.5. Sehingga indicator tersebut harus dihapus agar model menjadi valid. Selanjutnya dilakukan pengukuran untuk FL dan tidak terdapat FL dibawah 0.5, hasilnya seperti pada tabel dibawah. Selanjutnya dilakukan pengukuran cross loading dari setiap variabel yang ada. Nilai cross loading harus lebih besar dari nilai cross loading indicator terhadap variabel. Keseluruhan indicator dari setiap variabel memenuhi kriteria pengukuran inner model.

Tabel 6. Factor Loading (FL)

\begin{tabular}{llllll}
\hline Indikator & $\begin{array}{l}\text { Faktor } \\
\text { Loading }\end{array}$ & Indikator & $\begin{array}{l}\text { Faktor } \\
\text { Loading }\end{array}$ & Indikator & $\begin{array}{l}\text { Faktor } \\
\text { Loading }\end{array}$ \\
\hline X11 & 0.763 & X35 & 0.874 & X59 & 0.836 \\
X12 & 0.608 & X36 & 0.760 & X510 & 0.645 \\
X13 & 0.774 & X41 & 0.664 & Y1 & 0.780 \\
X14 & 0.842 & X42 & 0.806 & Y2 & 0.834 \\
X15 & 0.832 & X43 & 0.857 & Y3 & 0.752 \\
X16 & 0.794 & X44 & 0.871 & Y4 & 0.810 \\
X21 & 0.743 & X45 & 0.826 & Y5 & 0.688 \\
X22 & 0.810 & X46 & 0.771 & Y6 & 0.797 \\
X23 & 0.736 & X52 & 0.736 & Y8 & 0.861 \\
X24 & 0.809 & X54 & 0.770 & Y9 & 0.835 \\
X25 & 0.808 & X55 & 0.590 & Y10 & 0.533 \\
X26 & 0.695 & X56 & 0.883 & & \\
X32 & 0.784 & X57 & 0.724 & & \\
X33 & 0.651 & X58 & 0.820 & & \\
\hline
\end{tabular}

Pengukuran selanjutnya pada outer model adalah pengujian reabilitas pada kriteria setiap variabel. Pengujian reliabilitas meliputi Cronobach's Alfa (CA), Composite Reability (CR) dan Average Variance Extracted (AVE). Dengan kriteria uji model CA > 0.6, CR > 0.6 dan AVE > 0.5. Hasil Pengujian dapat dilihat pada gambar Gambar 4.

\begin{tabular}{|c|c|c|c|c|}
\hline & Cronbach's Alpha & rho_A & Composite Reliability & Average Variance Extracted (AVE) \\
\hline Interaksi (X2) & 0.860 & 0.863 & 0.896 & 0.590 \\
\hline Keberadaan Web (X1) & 0.863 & 0.875 & 0.898 & 0.597 \\
\hline Tingkat Partisipasi $(V)$ & 0.909 & 0.923 & 0.926 & 0.562 \\
\hline Transaksi (X3) & 0.771 & 0.786 & 0.853 & 0.595 \\
\hline Transformasi (X4) & 0.887 & 0.897 & 0.915 & 0.643 \\
\hline Usability (X5) & 0.883 & 0.898 & 0.907 & 0.528 \\
\hline
\end{tabular}

Gambar 4. Hasil Pengujian Reabilitas

Dari hasil pengujian outer model meliputi uji validitas dan reabilitas menunjukkan bahwa seluruh valiabel memenuhi kriteria pengujian. Sehingga model dapat dilakukan pengujian inner model.

\subsubsection{Evaluasi Inner Model}

Pengukuran inner model digunakan untuk melihat hubungan antara variabel dalam model serta untuk menguji hipotesis yang telah ditetapkan. Pada pengukuran inner model penulis menggunakan signifikasi Pvalue $<0.05$ (Signifikan). Selanjutnya untuk melihat hubungan antara variabel dengan melhat nilai path coefficients. Nilai path coefficients positif menunjukkan hubungan antar variabel positif, sedangkan untuk nilai negative menunjukkan hubungan negative antar variabel. Nilai Pvalue dan path coefficients dapat dilihat pada Tabel 7.

Tabel 7. Hasil Pengukuran Inner Model

\begin{tabular}{llll}
\hline Konstruk & Pvalues & Path Coefficients & Hasil Hipotesis \\
\hline H1: X1->Y & 0.355 & -0.066 & Ditolak \\
H2: X2->Y & 0.051 & 0.163 & Ditolak \\
H3: X3->Y & 0.235 & 0.084 & Ditolak \\
H4: X4->Y & 0.000 & 0.386 & Diterima* \\
H5: X5->Y & 0.000 & 0.439 & Diterima* \\
* Consistensi Pvalue $<0.05$ & & \\
\hline
\end{tabular}

Dari tabel diatas dapat dilihat bahwa ada 3 hipotesis ditolak dan 2 hipotesis yang diterima. Hipotesis yang diterima yaitu X4 (Dimensi Transformasi)->Y (Tingkat Partisipasi) dan X5 (Dimensi Usablity) -> Y (Tingkat 
Partisipasi). Hal ini menunjukkan bahwa faktor yang berpengaruh terhadap tingkat partisipasi publik menggunakan e-government adalah transformasi dan usability (kemudahan).

Sementara 3 hipotesis yang ditolak adalah X1 (Keberadaan Website) -> Y (Tingkat Partisipasi), X2 (Dimensi Interaksi) -> Y (Tingkat Partisipasi), X3 (Dimensi Transaksi) -> Y (Tingkat Partisipasi). Pada hipotesis tersebut tidak terbukti secara signifikan bahwa dimensi keberadaan website, dimensi interaksi, dan dimensi partisipasi berpengaruh terhadap tingkat partisipasi masyarakat dalam menggunakan e-government.

\section{KESIMPULAN}

E-government yang menjadi landasan transformasi birokrasi di Indonesia harus dibarengi dengan perubahan pola transformasi dan tata kelola e-government. Kabupaten Sukoharjo yang memiliki e-government telah berhasil diuji dengan menggunakan model Gartner. Tingkat kematangan e-government secara menyeluruh menunjukkan skor 4.06 (predictable process). Sementara setiap dimensi, model gartner mampu menunjukkan tingkat kematangan dimensi keberadaan website 4,08 (predictable process), dimensi interaksi 4,12 (predictable process), dimensi transaksi 3,98 (Estabilished process). Sementara pada 2 dimensi tambahan yaitu dimensi usability 4,01 (predictable process) dan dimensi partisipasi 4,05 (predictable process). Data yang digunakan pada analisa berasal dari hasil kuisioner dan hasil observasi.

Tingkat partisipasi e-government di kabupaten Sukoharjo dipengaruhi oleh dimensi Usability dan Transformasi. Dibuktikan dengan nilai Pvalue kurang dari signifikasi 0.05. Sementara 3 dimensi yang lain yaitu dimensi keberadaan, interaksi, dan transaksi tidak berpengaruh terhadap tingkat partisipasi masyarakat menggunakan e-government. Dari hal tersebut, model gartner yang paling berpengaruh terhadap tingkat partisipasi adalah dimensi transformasi dan dimensi usability. Sehingga dapat dimungkingkan model gartner juga terdapat variabel terkait dengan tingkat partisipasi publik.

\section{REFERENCES}

[1] B. Data and P. Dan, "Basis data peraturan dan perundang-undangan," Program. pp. 1-14, 2006.

[2] A. S. Edwi, "Evaluasi Implementasi E-government Pada Situs Web Pemerintah Daerah Di Indonesia: Prespektif Content dan Manajemen," Semin. Nas. Inform. 2008 (semnasIF 2008), vol. 2008, no. November 2007, pp. 88-98, 2008.

[3] D. Economic and Social Affairs, "United Nations e-government Survey 2018," United Nations, pp. 1-300, 2018.

[4] H. Dwi Apriyanto, Rudi. and Prihantono Putro, "Tingkat kegagalan dan keberhasilan proyek sistem informasi di indonesia," Semin. Nas. Teknol. Inf. dan Komun. 2018 (SENTIKA 2018), vol. 2018, no. Sentika, pp. 23-24, 2018.

[5] H. Rafizal and A. Author, "Fisibilitas Organisasi Implementasi e-government Berbasis Knowledge Management di Indonesia," no. April, 2018.

[6] A. Hasan and A. Arief, "Pemerintah Daerah Kepulauan," J. Protek, vol. 05, no. 1, pp. 31-36, 2018.

[7] A. Supriyanto and K. Mustofa, "E-gov readiness assessment to determine E-government maturity phase," Proceeding 2016 2nd Int. Conf. Sci. Inf. Technol. ICSITech 2016 Inf. Sci. Green Soc. Environ., pp. 270-275, 2017.

[8] S. N. As-Saber, A. Srivastava, and K. Hossain, "Information Technology Law and E-government :," vol. 1, no. 1, pp. 84-101, 2006.

[9] S. Al Marzooqi, E. Al Nuaimi, and N. Al Qirim, "E-governance (G2C) in the Public Sector: Citizens Acceptance to Egovernment Systems - Dubai's Case," Proc. Second Int. Conf. Internet Things, Data Cloud Comput., pp. 112:1112:11, 2017.

[10] S. Bayona and V. Morales, "Maturity model for local E-government: A case study," ACM Int. Conf. Proceeding Ser., vol. Part F1280, pp. 78-83, 2017.

[11] A. Chaushi, B. A. Chaushi, and F. Ismaili, "Measuring e-government Maturity: A meta-synthesis approach," SEEU Rev., vol. 11, no. 2, pp. 51-67, 2016.

[12] F. De Brí and F. Bannister, "E-government stage models: A contextual critique," Proc. Annu. Hawaii Int. Conf. Syst. Sci., vol. 2015-March, pp. 2222-2231, 2015.

[13] D. Napitupulu, "e-government Maturity Model Based on Systematic Review and Meta-Ethnography Approach," J. Bina Praja, vol. 8, no. 2, pp. 263-275, 2016.

[14] A. Shahkooh, Kolsoom Abbasi;Saghafi, Fatemeh;Abdollahi, "A Proposed Model for M-Banking Adoption," Informatics, vol. 07, pp. 231-239, 2010.

[15] T. W. A. N. P. dan Budi Guntoro, "Performance E-government Untuk Peningkatan Partisipasi Masyarakat Dalam Pembangunan Infrastruktur Di Kabupaten Sidoarjo," J. Kawistara, vol. 4, no. 3, 2014.

[16] A. Shahkooh, Kolsoom Abbasi;Saghafi, Fatemeh;Abdollahi, “A Proposed Model for Research,” Negot. J., vol. 07, pp. 231-239, 2008.

[17] J. F. Hair, C. M. Ringle, and M. Sarstedt, "PLS-SEM: Indeed a silver bullet," J. Mark. Theory Pract., vol. 19, no. 2, pp. 139-152, 2011. 